\title{
Physicochemical properties of vacuum packaged snake fruits in the presence of olive leave extract
}

\author{
1,3*Al-Baarri, A.N., ${ }^{2}$ Lestari, F.P., ${ }^{1}$ Wahda, H.M., ${ }^{2,3}$ Widayat, and ${ }^{1}$ Legowo, A.M. \\ ${ }^{1}$ Food Technology Department, Faculty of Animal and Agricultural Sciences, Diponegoro \\ University, Semarang, Indonesia \\ ${ }^{2}$ Chemical Engineering Department, Faculty of Engineering, Diponegoro University, Semarang, Indonesia \\ ${ }^{3}$ Integrated Laboratory Diponegoro University, Semarang, Indonesia
}

\author{
Article history: \\ Received: 15 September \\ 2019 \\ Received in revised form: 15 \\ February 2020 \\ Accepted: 20 February 2020 \\ Available Online: 26 \\ February 2020
}

\section{Keywords:}

Vacuum packaging,

Snake fruit,

Shelf-life,

Olive leave

\section{DOI:}

https://doi.org/10.26656/fr.2017.4(S1).S37

\begin{abstract}
This research was done to investigate the effectiveness of the presence of olive leaf extract in vacuum packaging in maintaining the physicochemical properties of fresh-cut snake fruit under ambient temperature. The snake fruits were vacuum packaged in the presence of 3\% ( $/ \mathrm{w})$ olive leave extract (OLE) and stored in room temperature for 8 days of storage. The physicochemical properties including color changes, firmness, and total dissolved solid (TDS) were observed. The results indicated that addition olive leaves extract in vacuum packaging gave the best result by inhibiting color changes by declining in total color difference by 10.88 , BI 5.08 , absorbance $2.750 \AA$ declining in hardness by $14.61 \%$ and lowest TDS level. As an alternative method of storing fresh-cut snake fruit under ambient conditions, vacuum packaging containing olive leave extract can be used.
\end{abstract}

\section{Introduction}

Fresh fruit sales are currently increasing rapidly due to the benefits of fresh products such as rich nutrition, fresh quality and consumer convenience (Altunkaya and Gokmen, 2011). Fresh fruits and vegetables are much more susceptible to deterioration than their entire fruits due to injury during preparation. Fresh-cut processing causes deterioration in the quality of tissue breakdown, resulting in metabolic, physicochemical and textural changes that limit the shelf-life of products (Tao et al., 2019). Wounding of fruit and vegetable tissues results in increased respiration and ethylene production, membrane degradation and an increase in the rate of biochemical reactions that are responsible for changes in quality characteristics and therefore a reduction in shelf life (Portela and Cantwell, 1998). Snake fruit has great potential as an export crop among exotic fruits (Lestari et al., 2013). Previous research showed that snake fruit is a good source of carbohydrates, dietary fibers and antioxidants (Aralas et al., 2015). Normally, snake fruits are consumed fresh. One of the obstacles in the processing of minimally processed snake fruit is its flesh discoloration due to an enzymatic browning reaction that causes the flesh to turn brownish soon after the bark has been peeled and the flesh has been cut (Aqilah et al., 2013).
Vacuum packaging, on the other hand, has proved especially suitable for products where oxygen can provoke chemical or biochemical alterations (Denoya et al., 2015). Therefore, fresh-cut fruits can potentially benefit from this technology, considering that oxygen is one of the substrates of the browning reactions. Polyphenols are the most abundant molecules in the olive leaves' bioactive profile. In particular, the secoiridoid oleuropein is the main compound together with other secoiridoids derived from the structure of tyrosol and flavonoids (Benavente-garcõâa et al., 2000). These compounds account for the antioxidant and antimicrobial activities of olive leaves extracts and could make olive leaf extracts suitable for use in the food industry and allow food product to have longer shelf-life (Difonzo et al., 2018). The addition of antioxidants in the packaging material provides advantages compared to the direct addition of food, such as lower amounts of active substances required, product-focused activity, controlled release into the food matrix, and the elimination of additional steps in the production process required for antioxidant addition (Bolumar et al., 2011). Antioxidant packaging can prevent food oxidation that can lead to off -flavor, changes in color and flavor and nutritional lose (Castellari et al., 2014). Previous studies (Moudache et al., 2016) showed that new active packaging containing olive leave extract has strong antioxidant activity and an 
active film containing olive leave extract also more susceptible for foods that are rich in lipids (Bastante et al., 2019). Hayes et al. (2011) and Moudache et al. (2017) reported that OLE improved lipid stability in meat products. Jiménez et al. (2016) and Zribi et al. (2013) showed an antioxidant effect of OLE in frying oil. In addition, different authors showed that OLE exhibits significant antioxidant activity, which could enhance the oxidative stability of vegetable oils (Rahmanian et al., 2015)

The aim of this study was to investigate the effectiveness of adding olive leave extract to color changes, total dissolved solids, and hardness during storage under ambient temperature in vacuum packaged snake fruits.

\section{Materials and methods}

\subsection{Fresh-cut preparation and treatment}

Snake fruits var. Pondoh were obtained from a local farm in Sleman, Yogyakarta, Indonesia at a similar size and ripen level. Non-defect fruits were selected and peeled. Fresh-cut snake fruit was prepared by cutting the fruit into two pieces and the seed removed.

The deseeded fruits containing 2-3 pieces $(50 \pm 5 \mathrm{~g})$ were vacuum packaged in $10 \mathrm{~cm} \times 10 \mathrm{~cm}$ vacuum bag with three different treatments. Cotton that has been dripped by $3 \%(\mathrm{v} / \mathrm{w})$ OLE were used as OLE treatment, while cotton that has been dripped by $3 \%(\mathrm{v} / \mathrm{w})$ distilled water were used as AQ treatment. Fruits then were stored in room temperature $\left(25 \pm 5^{\circ} \mathrm{C}\right)$ for 8 days of storage. The control samples were prepared as well by vacuum packing the fresh-cut snake fruit in absence of OLE and AQ and stored at the same condition as previously described. The treatment was replicated seven times.

\subsection{Olive leaves extraction}

Olive leaves (Devine) were obtained from OneHouse, Bogor, Indonesia. Water olive leave extracts were prepared from $10 \mathrm{~g}$ of powdered dried olive leaves by brewing in $100 \mathrm{~mL}$ distilled water at $100^{\circ} \mathrm{C}$ and stirred for 10 mins with a magnetic stirrer. The mixture then was filtered with filter cloth to separate the remaining leaves and the filtrate. The filtrate then was centrifuged using a Silogex Centrifuge at $1700 \mathrm{rpm}$ for 10 mins. The supernatant was separated and used as olive leave extract.

\subsection{Parameter analysis}

\subsubsection{Color determination}

Snake fruit juices were prepared by the method described by (Suhandy et al., 2010). A $10 \mathrm{~g}$ treated fresh -cut snake fruit were juiced and filtered with cloth in order to obtain juices. Changes in the juice of fresh cut snake fruit were determined immediately using a digital colorimeter (Apple, US) and were expressed as L*, a* and $b^{*}$ values. Total color difference $(\Delta \mathrm{E})$ of fresh-cut snake fruit during storage was calculated according to (Maskan, 2001) using the equation:

$$
\Delta \mathrm{E}=\left[\left(\mathrm{L}_{0}-\mathrm{L}_{\mathrm{t}}\right)^{2}+\left(\mathrm{a}_{0}-\mathrm{a}_{\mathrm{t}}\right)^{2}+\left(\mathrm{b}_{0}-\mathrm{b}_{\mathrm{t}}\right)^{2}\right]^{1 / 2}
$$

\subsubsection{Browning intensity}

Browning intensity in snake fruit juices was determined by the method according to (Supapvanich et al., 2012). A $20 \mathrm{~g}$ of fresh-cut snake fruit from seven replication was juiced using a commercial juice extractor (Miyako, Japan) and filtered with a cloth. The absorbance was measured immediately at $420 \mathrm{~nm}$ using a UV-Vis UV-1280 Spectrophotometer (Shimadzu, Japan).

The browning index (BI) was calculated as described by (Palou et al., 1999) using the equation:

$\mathrm{BI}=[(\mathrm{x}-0.31) / 0.172]$

Where,

$$
\mathrm{x}=\left[\left(\mathrm{a}^{*}+1.75 \mathrm{~L}\right) /\left(5.645 \mathrm{~L} *+\mathrm{a}^{*}-3.012 \mathrm{~b}^{*}\right)\right]
$$

The $\Delta \mathrm{BI}$ were calculated using the equation:

$$
\Delta \mathrm{E}=\mathrm{BI}_{\mathrm{t}}-\mathrm{BI}_{0}
$$

\subsubsection{Total Dissolved Solid (TDS) analysis}

Total Dissolve solid was performed by measuring the TDS value of snake fruit juices using a pocket TDS meter Ezdo 8200. The instrument was calibrated using a $1412 \mu \mathrm{S} / \mathrm{cm}$ standard solution kit. After being calibrated, the electrode of the instrument was dipped into the juice. The TDS was quantified in ppm.

\subsubsection{Texture Analysis}

Texture analysis was done by measuring the texture parameter analysis (TPA) parameters (Denoya, Vaudagna, and Polenta 2015) using a Brook Field CT-3 Texture Analyzer (Brook Field, US). The following condition was set: $4.5 \mathrm{~g}$ trigger, $3 \mathrm{~mm}$ deformation, $1 \mathrm{~m} /$ s speed. A sample with a $2 \mathrm{~cm} \times 1 \mathrm{~cm} \times 1 \mathrm{~cm}$ size was placed onto a platform and a $2.5 \mathrm{~mm}$ diameter cylindrical probe was used.

\section{Results and discussion}

3.1 Color changes and browning intensity in fresh-cut snake fruit

Changes in the color of snake fruit juices are shown by changes in $\mathrm{L}^{*}, \mathrm{a} *$ and $\mathrm{b}^{*}$ values. $\mathrm{L} *$ and $\mathrm{a} *$ are important in determining the browning intensity. Figure 
1 (a) Shows that the $\mathrm{L} *$ value decreased during storage in all treatments. The lowest change in $\mathrm{L} *$ value was observed in OLE (olive oil) treatment compared to treatment $\mathrm{K}$ (without treatment) and AQ (distilled water). Figure $1(\mathrm{~b})$ shows changes in the value of a $*$ in snake fruit juices, where a $*$ gradually increased over time. The same as changes in the $\mathrm{L} *$ value, in the OLE treatment the lowest $a^{*}$ value is also obtained. The value of $b *$ also increased during storage periods in the three treatments (Figure $1 \mathrm{c}$ ). The lowest change in the value of $b^{*}$ was obtained in the OLE treatment. A decrease in the value of $\mathrm{L}^{*}$ and an increase in the values of $\mathrm{a} *$ and $\mathrm{b} *$ indicate browning.
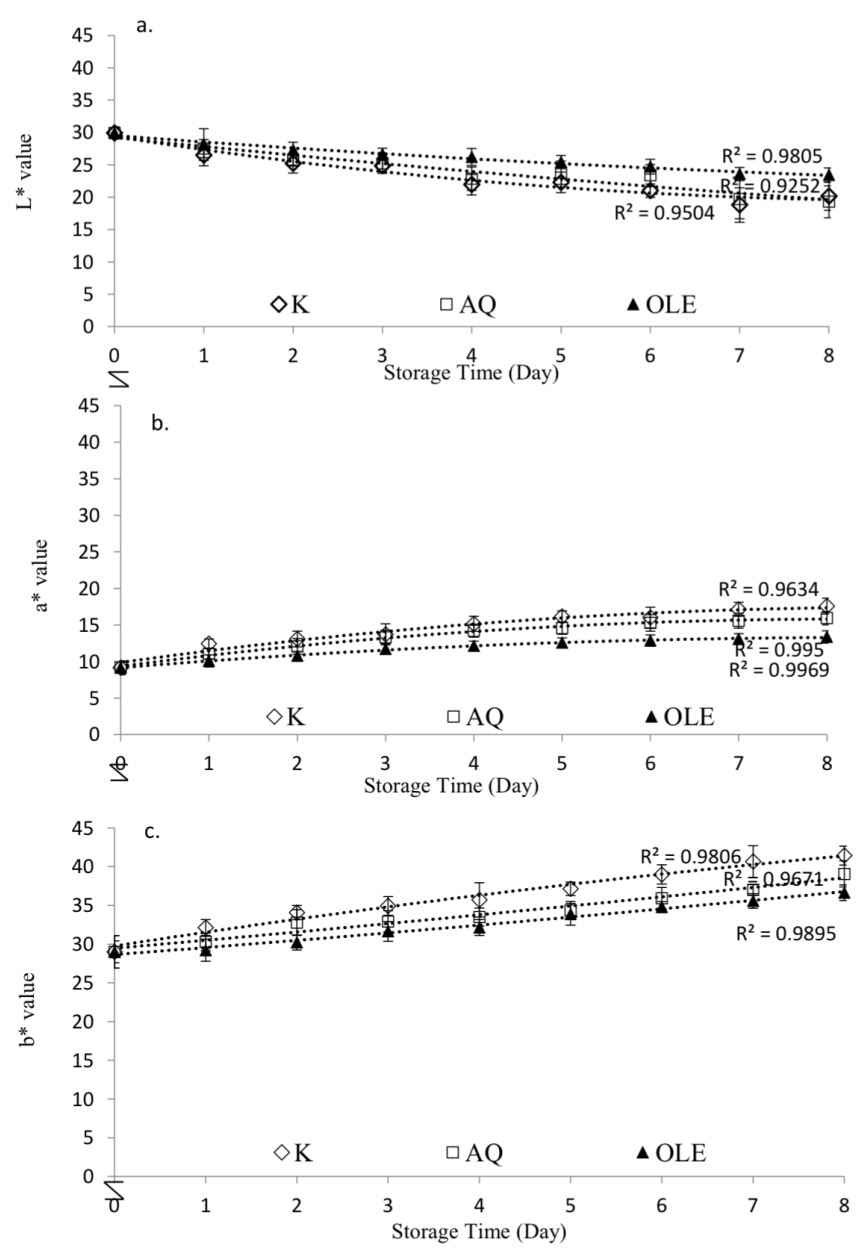

Figure 1. The change of Lab value of snake fruit during 8 days of storage in $\mathrm{K}, \mathrm{AQ}$, OLE treatments;(a) $\mathrm{L}^{*}$ value of juiced fresh-cut snake fruit; (b) $\mathrm{a}^{*}$ value of juiced fresh-cut snake fruit; and (c) $b^{*}$ value of juiced fresh-cut snake fruit

The total color difference and the Browning Index were also observed in treatments including $\mathrm{K}, \mathrm{AQ}$, and OLE with reference to the values obtained from $L^{*}, a *$, and $\mathrm{b} *$ observations for each 8-day storage Over storage periods, both $\Delta \mathrm{E}$ and $\Delta \mathrm{BI}$ have increased from each treatment. Snake fruit juices in K, AQ and OLE treatments are $17.92,16.15$, and 10.88 , respectively. In the meantime, $\Delta \mathrm{BI}$ for $\mathrm{K}, \mathrm{AQ}$, and OLE are 43.34, 36.66 and 5.08 respectively during 8 days of storage. The results of the $\Delta \mathrm{E}$ and $\Delta \mathrm{BI}$ calculations show that OLE treatment has the lowest level of $\mathrm{E}$ and $\mathrm{BI}$ compared to treatment $\mathrm{K}$ and $\mathrm{AQ}$, which shows that the level of browning in OLE treatment is lower than the other two treatments. Compared to treatments $\mathrm{K}$ and $\mathrm{AQ}$, this is indicated by the lowest $\mathrm{L}^{*}, \mathrm{a}^{*}, \Delta \mathrm{E}$, and $\Delta \mathrm{BI}$ values. The addition of olive leaves extracts as active packaging is suspected to help maintain the color of snake fruit juices by inhibiting oxidation reactions by reducing PPO activity during the fresh-cut storage process at room temperature. This result is similar to the application of film packaging material containing extracts of olive leaves that could retain the quality of the food product against oxidation process.

Besides measuring using the CIE $\mathrm{L} * \mathrm{a} * \mathrm{~b} *$ color indicator, spectral analysis was also performed to determine the color change in juiced fresh-cut snake fruit. Figure 2 shows the results of the snake fruit juices spectral analysis. Maximum absorbance at wavelength $420 \mathrm{~nm}$ on day 0 is $2.395 \AA$ while the maximum intake for $\mathrm{K}, \mathrm{AQ}$, and OLE treatments on the 8th day are 3.715 Á, $3.084 \AA$ Á, and $2.750 \AA$ Á, respectively. OLE treatment yields the lowest absorption value compared to $\mathrm{K}$ and AQ treatment. Due to lower PPO enzyme activity due to the addition of OLE during storage, low intake of OLE treatment is possible.

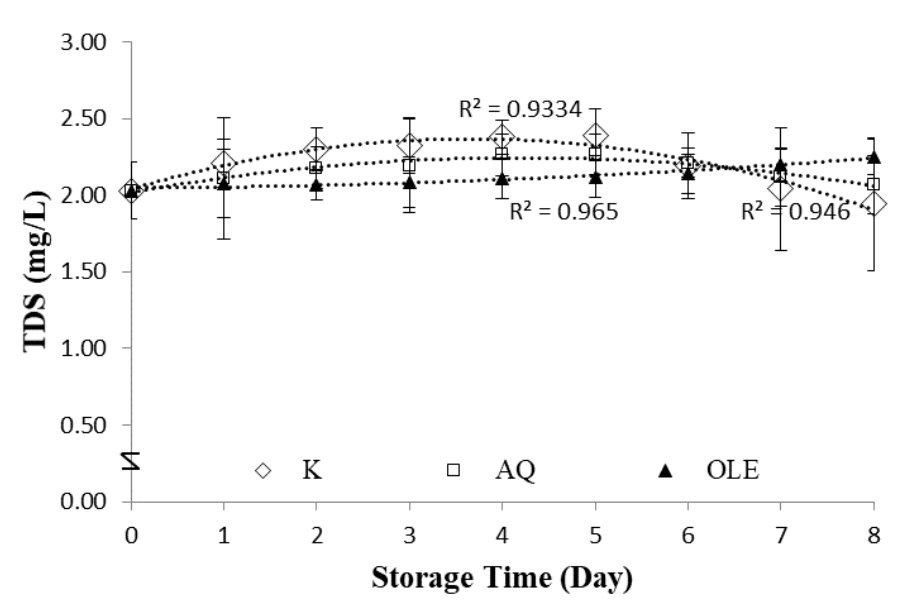

Figure 2. Total dissolved solid (TDS) value of fresh-cut snake fruit during 8 days of storage

\subsection{Total dissolved solids}

Another indicator used in the evaluation of minimally processed fruit is total dissolved solids. The lowest increase in TDS occurred in OLE treatment during 8 days of storage. Increasing the value of TDS during storage was due to the breaking process of starch into simple sugars due to the respiration process. Fruits that experience tissue damage as a result of mechanical processes tend to have higher respiration rates and increase the rate of cell damage (Toivonen and 
Brummell, 2008). In K and AQ, TDS decreased after 5 days of storage. This could be explained by the starch which is the substrate for the respiration process so that the simple sugar formed is lowered. In this case, the addition of antioxidants such as OLE helps to reduce the respiration rate, resulting in a slower breakdown of starch. A high respiration rate causes faster fruit deterioration. A slower respiration process enables the fruit to have a longer shelf life. This is also similar to the application of modified atmosphere packaging (MAP) combined with calcium chloride, which can extend the fresh-cut shelf life by reducing respiration rates, ethylene biosynthesis and transpiration (Punumong et al., 2016).

\subsection{Loss of hardness during storage}

Fruit hardness is an important factor in evaluating a correlation of physical appearance that affects the texture. Diminishing of firmness over storage periods affect the quality and shelf life of minimally processed food (Supapvanich et al., 2011). Figure 3 shows that the hardness level of the fruit has decreased over time during 8 days of storage. Declining of hardness on $\mathrm{K}, \mathrm{AQ}$, and OLE during 8 days of storage are $25.53 \%, 22.52 \%$, and $14.61 \%$, respectively. OLE showed better result compared to K and AQ. Similar results were found in the use of vacuum impregnation techniques on pear texture in the presence of an anti-browning agent (Perez-Cabrera et al., 2011). Peptic solubility in the cell wall and middle lamella cause the decrease in the hardness level. This is because of the increased synergistic activity of PME and PG. PG acts as a hydrolytic enzyme that increases its activity when tissue damage occurs. Adding olive leaves extract to the vacuum packaging can retain the snake fruit hardness level and inhibit tissue softening by delaying the ripening process so that the process of degradation of the cell wall becomes slower.

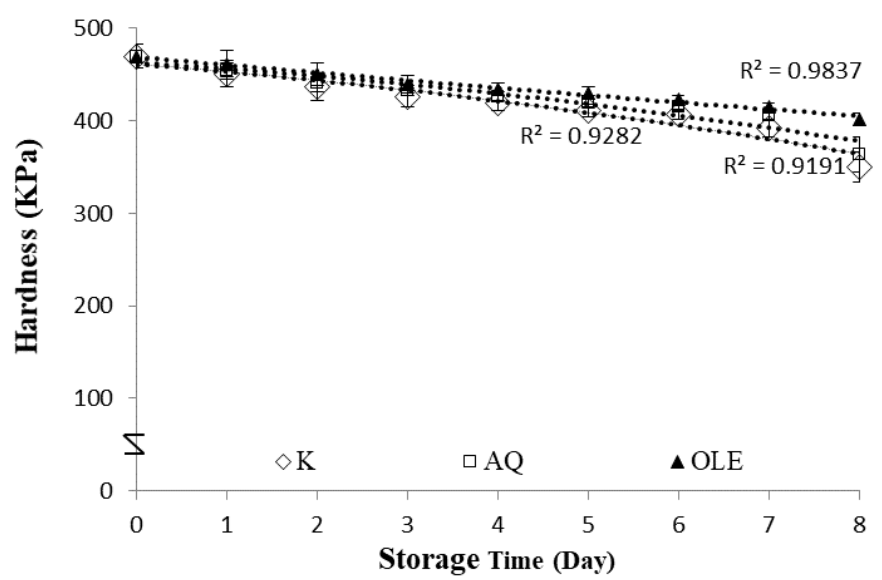

Figure 3. Loss of hardness of fresh-cut snake fruit during 8 days of storage

\section{Conclusion}

In order to maintain the quality of fresh cut snake fruit, OLE treatment showed the best result where the addition of OLE in vacuum packaging retarded the color of juiced fresh-cut snake fruit, TDS, and hardness of fresh-cut snake fruit. Combination of VP and OLE can be utilized to inhibit the oxidation process and prolong shelf-life of fresh cut snake fruit.

\section{Conflict of Interest}

The authors declare no conflict of interest.

\section{Acknowledgments}

The authors wish to thank Ministry of Research, Technology, and Higher Education of Indonesia and Diponegoro University for entirely supporting this research.

\section{References}

Altunkaya, A. and Gokmen, V. (2011). Effect of grape seed extract on phenolic profile and browning of fresh-cut lettuce (L. sativa). Journal of Food Biochemistry, 36(3), 1-7. https://doi.org/10.1111/ j.1745-4514.2010.00534.x

Aqilah, N., Zaini, M., Osman, A., Abdul Hamid, A., Ebrahimpour, A. and Saari, N. (2013). Purification and characterization of membrane-bound polyphenoloxidase ( $\mathrm{mPPO}$ ) from snake fruit [Salacca zalacca (Gaertn.) Voss]. Food Chemistry, 136(2), 407-414. https://doi.org/10.1016/ j.foodchem.2012.08.034

Aralas, S., Mohamed, M. and Bakar, M.F.A. (2015). Antioxidant properties of selected salak (Salacca zalacca) varieties in Sabah, Malaysia. Nutrition and Food Science, 2(4), 11-17.

Bastante, C.C., Cran, M.J., Cardoso, L.C., Serrano, C.M., Martínez De, E.J. and Bigger, S.W. (2019). Effect of supercritical $\mathrm{CO}_{2}$ and olive leaf extract on the structural, thermal and mechanical properties of an impregnated food packaging film. The Journal of Supercritical Fluids, 145, 181-191. https:// doi.org/10.1016/j.supflu.2018.12.009

Benavente-garcõâa, O., Castillo, J., Lorente, J., Ortun, A. and Del Rio, J.A. (2000). Antioxidant activity of phenolics extracted from Olea europaea L . leaves. Food Chemistry, 68(4), 457-462. https:// doi.org/10.1016/S0308-8146(99)00221-6

Bolumar, T., Andersen, M.L. and Orlien, V. (2011).Antioxidant active packaging for chicken meat processed by high pressure treatment. Food Chemistry, 129(4), 1406-1412. https:// 
doi.org/10.1016/j.foodchem.2011.05.082

Castellari, M., Marcos, B., Sa, C., Kappen, F., Schennink, G. and Arnau, J. (2014). Development of biodegradable films with antioxidant properties based on polyesters containing a -tocopherol and olive leaf extract for food packaging applications. Food Packaging and Shelf Life, 1(2), 140-150. https://doi.org/10.1016/j.fpsl.2014.04.002

Denoya, G.I., Vaudagna, S.R. and Polenta, G. (2015). Effect of high pressure processing and vacuum packaging on the preservation of fresh-cut peaches. LWT - Food Science and Technology, 62(1), 801806. https://doi.org/10.1016/j.lwt.2014.09.036

Difonzo, G., Pasqualone, A., Silletti, R., Cosmai, L., Summo, C., Paradiso, V.M. and Caponio, F. (2018). Use of olive leaf extract to reduce lipid oxidation of baked snacks. Food Research International, 108, 48 -56. https://doi.org/10.1016/j.foodres.2018.03.034

Hayes, J.E., Stepanyan, V., Allen, P., Grady, M.N.O. and Kerry, J.P. (2011). Evaluation of the effects of selected plant-derived nutraceuticals on the quality and shelf-life stability of raw and cooked pork sausages. LWT - Food Science and Technology, 44 (1), 164-172. https://doi.org/10.1016/ j.lwt.2010.05.020

Jiménez, P., García, P., Bustamante, A., Barriga, A. and Robert, P. (2016). Thermal stability of oils added with avocado (Persea americana cv. Hass) or olive (Olea europaea cv. Arbequina) leaf extracts during the french potatoes frying. Food Chemistry, 221, 123 -129 .

j.foodchem.2016.10.051

Lestari, R., Ebert, G. and Huyskens-keil, S. (2013). Fruit quality changes of salak 'Pondoh' fruits (Salacca Zalacca ( Gaertn.) Voss) during maturation and ripening. Journal of Food Research, 2(1), 204-216. https://doi.org/10.5539/jfr.v2n1p204

Maskan, M. (2001). Kinetics of colour change of kiwifruits during hot air and microwave drying. Journal of Food Engineering, 48(2), 169-175. https://doi.org/10.1016/S0260-8774(00)00154-0

Moudache, M., Colon, M., Nerín, C. and Zaidi, F. (2016). Phenolic content and antioxidant activity of olive by-products and antioxidant film containing olive leaf extract. Food Chemistry, 212, 521-527. https://doi.org/10.1016/j.foodchem.2016.06.001

Moudache, M., Nerín, C., Colon, M. and Zaidi, F. (2017). Antioxidant effect of an innovative active plastic film containing olive leaves extract on fresh pork meat and its evaluation by Raman spectroscopy. Food Chemistry, 229, 98-103. https:// doi.org/10.1016/j.foodchem.2017.02.023
Palou, E., Lopez-Malo, A., Barbosa-Canovas, G.V., Welti-Chanes, J. and Swanson, B.G. (1999). Polyphenoloxidase activity and color of blanched and high hydrostatic. Journal of Food Science, 64 (1), 42-45. https://doi.org/10.1111/j.13652621.1999.tb09857.x

Perez-Cabrera, L., Chafer, M., Chiralt, A. and GonzalezMartinez, C. (2011). Effectiveness of antibrowning agents applied by vacuum impregnation on minimally processed pear. LWT - Food Science and Technology, 44(10), 2273-2280. https:// doi.org/10.1016/j.lwt.2011.04.007

Portela, S.I. and Cantwell, M.I. (1998). Quality changes of minimally processed honeydew melons stored in air or controlled atmosphere. Postharvest Biology and Technology, 14(3), 351-357. https:// doi.org/10.1016/S0925-5214(98)00052-0

Punumong, P., Sangsuwan, J., Kim, S.M. and Rattanapanone, N. (2016). Combined effect of calcium chloride and modified atmosphere packaging on texture and quality of minimallyprocessed litchi fruit. Chiang Mai Journal of Science, 43(3), 556-569.

Rahmanian, N., Jafari, S.M. and Wani, T.A. (2015). Bioactive profile, dehydration, extraction and application of the bioactive components of olive leaves. Trends in Food Science and Technology, 42 (2), 150-172. https://doi.org/10.1016/ j.tifs.2014.12.009

Suhandy, D., Yulia, M., Kuncoro, S. and Rhinaldo, W. (2010). The measurement of soluble Solids content in snake fruit (Salacca Edulis Reinw) cv. pondoh using a portable Spectrometer. IFAC Proceedings Volumes, 43(26), 235-240. https:// doi.org/10.3182/20101206-3-JP-3009.00041

Supapvanich, S., Pimsaga, J. and Srisujan, P. (2011). Physicochemical changes in fresh-cut wax apple ( Syzygium samarangenese [Blume] merril and L.M. Perry) during storage. Food Chemistry, 127(3), 912917. https://doi.org/10.1016/j.foodchem.2011.01.058

Supapvanich, S., Prathaan, P. and Tepsorn, R. (2012). Postharvest Biology and Technology Browning inhibition in fresh-cut rose apple fruit cv. Taaptimjaan using konjac glucomannan coating incorporated with pineapple fruit extract. Postharvest Biology and Technology, 73, 46-49. https://doi.org/10.1016/j.postharvbio.2012.05.013

Tao, R., Zhang, F., Tang, Q., Xu, C., Ni, Z. and Meng, $X$. (2019). Effects of curcumin-based photodynamic treatment on the storage quality of fresh-cut apples. Food Chemistry 274, 415-421. https:// doi.org/10.1016/j.foodchem.2018.08.042 
Toivonen, P.M.A. and Brummell, D.A. (2008). Biochemical bases of appearance and texture changes in fresh-cut fruit and vegetables. Postharvest Biology and Technology, 48(1), 1-14. https://doi.org/10.1016/j.postharvbio.2007.09.004

Zribi, A., Gargouri, B., Jabeur, H., Rebai, A., Abdelhedi, R. and Bouaziz, M. (2013). Enrichment of panfrying refined oils with olive leaf phenolic-rich extract to extend the usage life. European Journal of Lipid Science and Technology, 115(12), 1443-1453. https://doi.org/10.1002/ejlt.201300037 